\title{
Keys for successful reconstruction of mandibular defects using three-dimensionally printed patient-specific titanium implants
}

\author{
Jin-Wook Kim, DDS, PhD \\ Section Editor of JKAOMS \\ Department of Oral and Maxillofacial Surgery, School of Dentistry, Kyungpook National University, Daegu, Korea
}

Oral and maxillofacial surgeons often perform mandibular resection procedures during operations to treat various diseases, such as tumors, oral cavity cancers, and infectious diseases. For surgeons, every surgery is a challenge, no matter how experienced oral and maxillofacial surgeons are. Mandibular resection surgery leads to several severe problems that have to be fixed. These problems include the recovery of mandibular continuity, condylar reposition, soft tissue cover, and rehabilitation of occlusion.

To overcome these problems, broadly, there are two reconstruction methods: autogenous bone graft and reconstruction plate (R-plate) reconstruction. Fibula free flap is the gold standard method for long mandibular defects, and it is very useful for the recovery of mandibular continuity, soft tissue, and occlusion with preoperative planning using the computeraided design/computer-aided manufacturing technique. Furthermore, virtual surgical planning decreased surgical time and admission days and increased accuracy ${ }^{1,2}$. However, the disadvantages of free flap include donor site morbidity and a long recovery process with delayed function or increased risk of recurrence due to delayed radiotherapy. Particularly, some elderly patients with multiple medical problems cannot stand such kind of surgery. Thus, when surgeons cannot choose free flap, the second choice is reconstruction with R-plate. However, conventional R-plate reconstruction is known to have severe problems, including loosening of screws, fracture

\footnotetext{
Jin-Wook Kim

Department of Oral and Maxillofacial Surgery, School of Dentistry, Kyungpook National University, 2177 Dalgubeol-daero, Jung-gu, Daegu 41940, Korea

TEL: +82-53-600-7575

E-mail:vocaleo@knu.ac.kr

ORCID: https://orcid.org/0000-0003-4074-877X
}

(c) This is an open-access article distributed under the terms of the Creative Commons Attribution Non-Commercial License (http://creativecommons.org/ licenses/by-nc/4.0/), which permits unrestricted non-commercial use, distribution, and reproduction in any medium, provided the original work is properly cited.

Copyright (C) 2021 The Korean Association of Oral and Maxillofacial Surgeons. of plate, soft tissue perforation, and impassibility of occlusal rehabilitation.

Three-dimensionally (3D) printed patient-specific titanium implants (PSTI) resolve almost all problems of free flap and R-plate reconstruction. Through presurgical virtual planning, PSTI decrease surgical time, duration of hospitalization, and postoperative morbidity and increase accuracy, esthetics by meeting 3D shape, and volume ${ }^{3,4}$. Mechanical properties and biocompatibility of titanium alloy and direct and increased contact surface with bone can reduce the risk of screw loosening and fracture. The published disadvantages of PSTI are mainly about economics, long duration of performance, and lack of flexibility during surgery ${ }^{5}$. However, in the near future, these advantages will be solved through competition between companies and insurance.

Besides the published and known disadvantages, there are some problems that have to be considered for planning. First, soft tissue coverage methods are considered. Primary sutured gingival or soft tissue defects laid over titanium plate placement do not ensure a normal healing process. Even small perforated gingiva can lead to implant removal. If soft tissue excision was planned, soft tissue graft, such as free or axial pattern flap, must be planned together and its margin should be on the remaining bone. The second considering point is whether to restore dentition or not. Many authors reported their specific implant designs to restore dentition ${ }^{4,6,7}$. The technical method of connection between the reconstruction and dental implant will not be the matter. Soft tissue management to access the dental implant is an important risk factor. During this procedure, exposing the reconstruction implant occurs inevitably. As there is no barrier to resist infection, postoperative infection can easily occur. In the worst case, removal of the implant may be needed. To successfully restore dentition, a specific implant design to contain bone substances may be required. 
In various cases, PSTI is being used globally, as it has various advantages. However, oral and maxillofacial surgeons must keep in mind that there are also important factors affecting its final success. The decision of soft tissue reconstruction and restoration of dentition are key points for successful mandibular reconstruction with PSTI.

\section{Conflict of Interest}

No potential conflict of interest relevant to this article was reported.

\section{References}

1. Tang NSJ, Ahmadi I, Ramakrishnan A. Virtual surgical planning in fibula free flap head and neck reconstruction: a systematic review and meta-analysis. J Plast Reconstr Aesthet Surg 2019;72:1465-77. https://doi.org/10.1016/j.bjps.2019.06.013

2. Barr ML, Haveles CS, Rezzadeh KS, Nolan IT, Castro R, Lee $\mathrm{JC}$, et al. Virtual surgical planning for mandibular reconstruction with the fibula free flap: a systematic review and metaanalysis. Ann Plast Surg 2020;84:117-22. https://doi.org/10.1097/ SAP.0000000000002006

3. Suska F, Kjeller G, Tarnow P, Hryha E, Nyborg L, Snis A, et al. Electron beam melting manufacturing technology for individually manufactured jaw prosthesis: a case report. J Oral Maxillofac Surg 2016;74:1706.e1-15. https://doi.org/10.1016/j.joms.2016.03.046

4. Lee UL, Kwon JS, Woo SH, Choi YJ. Simultaneous bimaxillary surgery and mandibular reconstruction with a 3-dimensional printed titanium implant fabricated by electron beam melting: a preliminary mechanical testing of the printed mandible. J Oral Maxillofac Surg 2016;74:1501.e1-15. https://doi.org/10.1016/ j.joms.2016.02.031

5. Goodson AM, Kittur MA, Evans PL, Williams EM. Patientspecific, printed titanium implants for reconstruction of mandibular continuity defects: a systematic review of the evidence. J Craniomaxillofac Surg 2019;47:968-76. https://doi.org/10.1016/ j.jcms.2019.02.010

6. Park JH, Odkhuu M, Cho S, Li J, Park BY, Kim JW. 3D-printed titanium implant with pre-mounted dental implants for mandible reconstruction: a case report. Maxillofac Plast Reconstr Surg 2020;42:28. https://doi.org/10.1186/s40902-020-00272-5

7. U V, Mehrotra D, Howlader D, Singh PK, Gupta S. Patient specific three-dimensional implant for reconstruction of complex mandibular defect. J Craniofac Surg 2019;30:e308-11. https://doi. org/10.1097/SCS.0000000000005228

How to cite this article: Kim JW. Keys for successful reconstruction of mandibular defects using three-dimensionally printed patient-specific titanium implants. J Korean Assoc Oral Maxillofac Surg 2021;47:237-238. https://doi.org/10.5125/jkaoms.2021.47.4.237 